4. Deming, J., and Washburn, A. H.: Respiration in infancy. 1. A method of studying rates, volume and character of respiration with preliminary report of results. Amer. J. Dis. Child., 49: 108 (1935)

5. Dittrichova, J., and Paul, K.: Respiratory rate during quiet sleep in high risk infants during the first six months of life. In: P. Levin and W. P. Koella: Sleep 1974: Second European Congress on Sleep Research, Rome, 1974, p. 417 (Karger, Basel, 1975).

6. Dixon, W. J.: Biomedical Computer Programs (University of California Press, Berkeley, 1975).

7. Edwards, A. L.: Experimental design in psychological research, 3rd Ed. p. 441 (Holt, Rinehart and Winston, 1968)

8. Evsywkova, 1.: Heart rate and respiration in newborn infants during different phases of sleep. Z. Evol. Biokhim. Fiziol., 10: 267 (1974).

9. Harper, R. M., Hoppenbrouwers, T., Sterman, M. B., McGinty, D. J., and Hodgman, J. E.: Polygraphic studies of normal infants during the first six months of life. $I$. Heart rate and variability as a function of state. Pediat. Res., 10: 945 (1976).

10. Mason, J., Harper, R. M., and Pacheco, R.: Analysis of respiratory data during sleep and waking. Proc. Dig. Equip. Comput. Users Soc., p. 567 (1974).

11. Harper, R. M., Hoppenbrouwers, T., Bannett, D., Hodgman, J. E., Sterman, M. B., and McGinty, D. J.: Effects of feeding on state and cardiac regulation in the infant. Develop. Psychobiol. (In press).

12. Lenard, H. G.: The development of sleep spindles in the EEG during the first two years of life. Neuropädiatrie, 1: 264 (1970).

13. Metcalf, D. R.: Sleep spindle ontogenesis. Neuropädiat., 1: 428 (1970)

14. Monod, N., and Pajot, N.: Le sommeil du nouveau-né et du prematuré $I$. Analyse des études polygraphiques. Biol. Neonate, 8: 281 (1965).

15. Murphy, D. P., and Thorpe, E. S.: Breathing measurements on normal newborn infants. J. Clin. Invest., 10: 545 (1931)

16. Parmelee, A. H., Wenner, W. H., Akiyama, Y., Schultz, M., and Stern, E.: Sleep states in premature infants. Develop. Med. Child. Neurol., 9: 70 (1967).

17. Paul, K., Dittrichova, J., and Pavlikova, E.: The course of quiet sleep in infants. Biol. Neonate, 23: 78 (1973).
18. Prechtl, H. F. R., Weinmann, H., and Akiyama, Y.: Organization of physiological parameters in normal and neurologically abnormal infants. Neuropädiatrie, $l: 101$ (1969).

19. Radvanji, M. F., Monod, N. and Dreyfus-Brisac, C.: Sleep cycle organization in newborn babies with respiratory distress syndrome. In: P. Levin and $W$. P. Koella: Sleep 1974. Second European Congress on Sleep Research, Rome, 1974, p. 428 (Karger, Basel, 1975).

20. Roffwarg, H. P., Muzio, J. N., and Dement, W. C.: Ontogenetic development of the human sleep-dream cycle. Science, 152: 604 (1966).

21. Sterman, M. B., Harper, R. M., Havens, B., Hoppenbrouwers, T., McGinty, D. J., and Hodgman, J. E.: Quantitative analysis of central cortical EEG activity during quiet sleep in infants from birth to six months of age. Electroencephal. Clin. Neurophysiol., 43: 371 (1977).

22. Theorell, K. Prechtl, H. F, R and Vos, J. E.: A polygraphic study of normal and abnormal newborn infants. Neuropädiatrie, 5: 279 (1974).

23. Usher, R., and McLean, F.: Intrauterine growth of live-born Caucasian infants at sea level: Standards obtained from measurements in seven dimensions of infants born between 25 and 44 weeks of gestation. J. Pediat. 74: 901 (1969)

24. The authors acknowledge the assistance of the Biomedical Engineering Departments and the Computing Center at the VA Hospital in Sepulveda. We thank Dr. E. Gocka and Mr. Leeds for their statistical help. J. R. Mason, D. Bannett, and D. Hockin were in charge of computer analysis. Ms. Havens, Hofmann, and Geidel shared responsibility for the monitoring laboratory and together with other specially trained nurses collected the data.

25. This research was supported by the National Institute of Child Health and Human Development Contracts NO1-HD-2-2777 and HD 4-2810.

26. Requests for reprints should be addressed to: $T$. Hoppenbrouwers, $P h . D$. Director Sudden Infant Death Syndrome (SIDS) Research Project, Room 4L40B, Women's Hospital, LAC/USC Medical Center, 1240 Mission Road, Los Angeles, CA 90033 (USA). [Tele: (213) 226-3266; (213) 894 8271, ext. 2403.]

27. Received for publication September 14, 1976.

28. Accepted for publication May 25,1977 .
Cystathionase cystathionine cystathioninuria genetic heterogeneity long term lymphoid lines pyridoxalphosphate vitamin-responsive amino aciduria

\title{
Cystathionase Deficiency: Evidence for Genetic Heterogeneity in Primary Cystathioninuria
}

\author{
THERESA A. PASCAL, ${ }^{(49)}$ GERALD E. GAULL, NICHOLAS G. BERATIS, BRUCE M. GILLAM,
} AND HARRIS H. TALLAN

\author{
Department of Human Development and Genetics, New York State Institute for Basic Research in \\ Mental Retardation, Staten Island, and Division of Medical Genetics, Department of Pediatrics, Mount Sinai School \\ of Medicine of the City University of New York, New York, USA
}

\section{Summary}

Optimal conditions are described for measurement of cystathionase activity in long term lymphoid cell lines. In 21 control lines established from normal subjects, cystathionase (EC 4.4.1.1) specific activity was $25.8 \pm 1.7$ (mean \pm SE) nmole cysteine/hr/mg protein. Extracts of three lymphoid lines (NB36, NB-95, and NB-77) established from three vitamin $B_{6}$ responsive patients with primary cystathioninuria had activity of 3.6-7.3; from a $B_{6}$-unresponsive patient (NB-68) had no detectable activity; from five obligate heterozygotes for cystathioninuria had activity of 11.2-18.9.

Two, or possibly three, different modifications of the cystathionase molecule could be demonstrated in cultured cells from the patients with primary cystathioninuria, based on the effects of added pyridoxal phosphate (PLP) in the enzyme assay, on the extent of reaction with rabbit antihuman hepatic cystathionase, and on the ability to compete with normal lymphoid cell line enzyme extract for the antibody combining sites. When PLP is not added to the assay system, the normal enzyme extract still had $89 \%$ of its activity in $1.0 \mathrm{mM}$ PLP; on agar double diffusion analysis it gave a band of identity with normal human hepatic cystathionase; the precipitin band had cystathionase activity, but inhibition by antibody could be shown in solution. Lymphoid line extract from the $B_{6}$-unresponsive patient had no detectable activity in the absence or presence of PLP, did not form a precipitin band, and did not compete with normal enzyme extract for the antibody combining sites. Thus, synthesis of apocystathionase is absent or significantly reduced; alternatively, the protein produced has lost its antigenic determinants 
as well as catalytic activity. Extracts of the three cell lines established from the three $B_{6}$-responsive patients had no activity in the absence of added PLP, but progressively greater activity was found with increasing concentrations of PLP: at $1.0 \mathrm{mM}$ PLP 37, 26, and $16 \%$ of the mean normal value, respectively, was attained. Cell extract from each of the $B_{6}$-responsive patients formed a band of identity with normal enzyme on agar double diffusion and cystathionase activity could be demonstrated on the precipitin band only if PLP was added to the extracts before immunodiffusion. Extract of the $B_{6}$-responsive lymphoid cell line NB-36 combined with the antibody sites for cystathionase, thereby blocking inhibition of normal enzyme, whereas extract of the line NB-95 had only a slight blocking effect and extract of the line NB-77 had no blocking ability. Thus, the lymphoid cell lines from the three $B_{6}$-responsive patients produce a cystathionase with an altered capacity to combine with PLP; the enzyme in lines NB-95 and NB-77 also may have been affected in a manner which changes as well the ability to compete for the antibody combining site. These altered cystathionases, both $B_{6}$-responsive and $B_{6}$-unresponsive, also may represent forms more readily degradable than the normal enzyme.

Antigenic identity was shown for cystathionase from various organs within a given vertebrate species, but only partial identity was observed among cystathionases from different vertebrate species.

\section{Speculation}

Primary cystathioninuria is caused by different mutations affecting the cystathionase molecule. One form of cystathioninuria, vitamin $B_{6}$-unresponsive, appears to result from absence of synthesis of the enzyme protein. $B_{6}$-responsive forms appear to result from production of cystathionase molecules altered in ability to combine with coenzyme, but with antigenic identity on agar double diffusion analysis maintained; in some cases, there may be changes in antibody binding capacity as well, although immunologic cross-reactivity remains.

Insight into the nature of inherited enzymatic deficiencies has been provided in recent years by use of immunologic procedures, i.e., development of antibodies to the normal enzyme and cross-reaction with preparations of deficient enzyme from affected individuals. In some cases the presence of a functionless enzyme protein which is antigenically indistinguishable from the normal enzyme could be demonstrated $(23,43)$, whereas in other cases no synthesis of any immunoreactive protein could be detected $(1,30)$. The present report is concerned with the application of such immunologic techniques to the investigation of primary cystathioninuria, an inborn error resulting from an inherited deficiency of cystathionase activity (EC 4.4.1.1). This enzyme acts to cleave cystathionine, a key intermediate on the transsulfuration pathway, to cysteine and 2-oxobutyrate. Primary cystathioninuria was first described by Harris et al. (16) in a patient with severe mental deficiency. Numerous other cases with a variety of clinical symptoms have been reported (11, 26). Furthermore, several reports of cystathioninuria in healthy individuals have appeared $(20,33)$, leading to the suggestion that mental deficiency and other clinical manifestations may not be causally related to the enzymatic defect.

Primary cystathioninuria is of particular interest, since it appears to be a genetically heterogeneous condition. Vitamin dependence has been demonstrated in a majority of patients, the excretion of cystathionine decreasing after administration of vitamin $B_{6}(11,33,35)$, but it has not been found in two other cases $(17,41)$. PLP, the coenzymatically active form of vitamin $B_{6}$, has been demonstrated to be the coenzyme for rat liver cystathionase $(6,21)$. Its effect on the cystathionase from patients with cystathioninuria has been studied, but with hitherto inconclusive results. Finkelstein et al. (9) found that cystathio- nase activity in an extract of liver from a $B_{6}$-responsive patient with primary cystathioninuria was strikingly lower than normal values; addition of $0.05 \mathrm{mM}$ PLP increased the activity, but the increase was no more than that which occurred in extracts of normal liver. The effect of larger concentrations of PLP was not tested because there was a limited quantity of liver available from the biopsy. Frimpter (11), on the other hand, observed a larger increase in cystathionase activity in extracts of liver from patients than was observed in extracts of normal liver, when PLP (at an unspecified concentration) was added to the incubation medium. Frimpter's experiments, however, neither demonstrated that the effect of the added PLP was directly on cystathionase, rather than on some other pathway of cysteine formation, nor ruled out the possibility of an effect on a nonenzymatic cleavage of cystathionine (36).

Using long term lymphoid cell lines, a more convenient and abundant source of enzyme than liver biopsy material, we have examined the immunological and structural properties of cystathionase from three cases of vitamin $B_{6}$-responsive cystathioninuria, from some related obligate heterozygotes, and from one case of vitamin $B_{6}$-unresponsive cystathioninuria. The direct effect of PLP on the deficient enzymes from all three of the $B_{6^{-}}$ responsive patients has been demonstrated unequivocally. In addition, immunologic procedures have been employed for an investigation of the cystathionases of various vertebrate species, in different organs, and in liver from fetal rat and monkey.

\section{MATERIALS AND METHODS}

\section{TISSUE CULTURE}

Long term lymphoid cell lines from peripheral blood leucocytes were established after stimulation of the lymphocytes with phytohemagglutinin (3). Lines NB-36 (35), NB-95 (38), and NB-77 (38) were established from $\mathrm{B}_{6}$-responsive patients with primary cystathioninuria. Line NB-68 (41) was established from a unresponsive patient. Clinical descriptions are to be found in the references cited. Five lymphoid lines were derived from the obligate heterozygous parents of the $B_{6}$-responsive patients with cystathioninuria. Lymphoid lines from 21 normal subjects were used as controls. Skin fibroblasts and amniotic fluid cells from normal subjects were cultured as described earlier (10).

\section{EXTRACT OF ORGANS}

Human brain and kidney, fetal and adult monkey liver, fetal rat liver, and rat kidney were homogenized with $0.03 \mathrm{M}$ potassium phosphate buffer, $\mathrm{pH} 6.9$, containing $1.0 \mathrm{mM}$ disodium EDTA, $1.0 \mathrm{mM}$ dithiothreitol, $50 \mu \mathrm{M}$ PLP. Each crude homogenate was centrifuged at $43,500 \times g$ for $1 \mathrm{hr}$, dialyzed overnight against the same buffer, and lyophilized. Ammonium sulfate preparations of rat and human liver were obtained as previously described (42).

\section{ENZYME ASSAYS}

Cystathionase was assayed in cell lysates prepared by freezing and thawing, under conditions established as optimal for normal long term lymphoid cell lines. In a total of $0.5 \mathrm{ml}$ the enzyme extract was incubated for $3.5 \mathrm{hr}$ with a mixture containing the following, in micromoles: Tris- $\mathrm{HCl}$ buffer ( $\mathrm{pH} \mathrm{9.2),} \mathrm{50;} \mathrm{PLP,}$ 0.125 ; EDTA, 0.2 ; cystathionine, 2.5 . Bovine serum albumin $(0.1 \mathrm{mg})$ was added in order to aid enzyme stability. This mixture was brought to $\mathrm{pH}$ 8.6. The cysteine formed was measured directly, either colorimetrically with acid ninhydrin (12) or radioactively with $\mathrm{L}-\left[{ }^{35} S\right]$ cystathionine as substrate $(27$, 28 ). The identity of the radioactive cysteine produced by lysates of normal cells and by lysates of cells from $B_{6}$-responsive patients was confirmed by oxidation to cysteic acid and separation by high voltage electrophoresis (32). Enzymatic activity is expressed as nanomoles of cysteine formed per $\mathrm{mg}$ protein per 
hr. Unless otherwise stated, the values are the results of duplicate determinations. The activities of $S$-adenosylmethionine decarboxylase (EC 4.1.1.50), a $\mathrm{B}_{6}$-dependent enzyme, and of $N^{5}$-methyltetrahydrofolate homocysteine methyltransferase (EC 2.1.1.13) were measured in cell lysates by published methods $(8,40)$. Protein concentrations were determined according to the method of Lowry et al. (19).

\section{AGAROSE DOUBLE IMMUNODIFFUSION AND IMMUNOELECTROPHORESIS}

Microimmunodiffusion plates with pattern " $C$ " or " $D$ " from Hyland Laboratories or IDF Cell 11 from Cordis Laboratories were used. Two-dimensional immunoelectrophoresis was performed according to the method of Scheidegger (31) in a Gelman electrophoresis chamber no. 51170. Electrophoresis proceeded for $2-3 \mathrm{hr}$ at $4^{\circ}$ with $0.05 \mathrm{M}$ sodium barbital buffer (pH 8.2) at 10-20 mA/Gelman electrophoresis frame. Antiserum to human liver cystathionase was obtained as described elsewhere $(24,25)$. The antiserum used for these studies was absorbed with lyophilized human plasma proteins $(60 \mathrm{mg} / \mathrm{ml})$. Diffusion took place at room temperature or $4^{\circ}$ for $24 \mathrm{hr}$.

\section{ENZYME STAIN OF IMMUNE PRECIPITATES}

After electrophoresis the slides were stained for cystathionase activity (24). Enzymatic activity usually is retained by an enzyme-antienzyme complex because the antibody seldom combines with the enzyme at the catalytic site. On the other hand, complete inhibition of catalytic activity takes place more readily in solution in the presence of antibody excess, whereby steric hindrance by the antibody is maximized (44).

\section{INHIBITION OF ENZYME ACTIVITY BY ANTISERUM}

Antiserum used for the inhibition studies contained faint traces of two to three antibodies to contaminating proteins. A $\gamma$ globulin fraction was obtained (2) and concentrated to a protein content of $28 \mathrm{mg} / \mathrm{ml}$. Extracts of normal or of $B_{6^{-}}$ responsive cells were preincubated at $37^{\circ}$ for $40 \mathrm{~min}$ with increasing amounts of the $\gamma$ globulin fraction. Cystathionase activity then was measured in the presence of the precipitate formed by the enzyme-antibody complex and expressed as percentage of inhibition by comparison with the activity obtained without addition of antiserum. This inhibition procedure is not affected by possible coprecipitation of the cystathionase protein with trace amounts of contaminating antigen-antibody complexes (18).

\section{COMPETITION FOR ANTIBODY BINDING SITES FOR CYSTATHIONASE}

Crude extracts from the abnormal cell lines, containing 0.4 $0.7 \mathrm{mg}$ protein, were preincubated separately at $37^{\circ}$ for $40 \mathrm{~min}$ with an amount of $\gamma$-globulin fraction of antiserum previously shown to produce approximately $50 \%$ inhibition of cystathionase activity in an extract of normal cells. The normal cell extract (0.43-0.52 $\mathrm{mg}$ protein) was then added and the mixture incubated again for $40 \mathrm{~min}$. After the second incubation, substrate was added and cystathionase activity was assayed without the addition of PLP in order to measure only the normal enzyme (see Results).

\section{RESULTS}

The cystathionase assay used in the present work incorporates several modifications of the conditions utilized for assay of cystathionase in various organs $(12,28)$ and provides optimal conditions for measurement of cystathionase activity in long term lymphoid cell lines (Fig. 1). The rate of reaction was greatest at $\mathrm{pH} 8.7$ in the presence of $5.0 \mathrm{mM}$ substrate. Production of cysteine was proportional to the amount of cellular protein added up to $1.0 \mathrm{mg} /$ tube. The course of the reaction remained linear up to $4.5 \mathrm{hr}$. Cystathionase activity was greatest at a coenzyme (PLP) concentration of $0.75 \mathrm{mM}$ (cf. Fig. 3). Routine assays were performed, however, with $0.25 \mathrm{mM}$ PLP, since tripling the concentration to $0.75 \mathrm{mM}$ resulted in only a slight increase in cystathionase activity. No cysteine was formed when the crude cell extracts were boiled before incubation.

Cystathionase specific activity in 21 control long term lymphoid cell lines, measured in the presence of $0.25 \mathrm{mM}$ PLP, was $25.8 \pm 1.7$ (mean \pm SE) nmol cysteine/mg protein/hr (Fig. 2). Values obtained with extracts of cells from the three $B_{6}$-responsive patients with primary cystathioninuria (lines NB-77, NB36 , NB-95) ranged from 3.6 to $7.3 \mathrm{nmol} / \mathrm{mg}$ protein/hr and did not overlap the normal values. No activity was observed in extracts of cells from the $B_{6}$-unresponsive patient (line NB-68). Extracts of cells from five obligate heterozygotes had specific activities of 11.2-18.9, which were intermediate between the mean control value and those of the affected lines, but which overlapped the lower end of the normal range. Cystathionase activity in extracts of eight normal skin fibroblast lines ranged from $0-7.9 \mathrm{nmol} / \mathrm{mg}$ protein/hr. Although cystathionase has been found to be virtually absent from the liver of the human fetus $(24,39)$, activity could be measured in cultured amniotic fluid cells, ranging from $7.3-19.8 \mathrm{nmol} / \mathrm{mg}$ protein $/ \mathrm{hr}$ in five normal cases.

Activities of $S$-adenosylmethionine decarboxylase and of $N^{5}$ methyltetrahydrofolate-homocysteine methyltransferase were measured in extracts of the affected cells in order to demonstrate that these cells were metabolically active, despite the reduction or absence of cystathionase activity. These activities were found to be within the normal range. Addition of an extract of each of the abnormal cells to an extract of normal cells did not inhibit cystathionase activity, demonstrating that the reduction or lack of enzymatic activity was not caused by a soluble inhibitor present in the abnormal cells.

In the absence of added PLP, the extract of normal cells still had considerable cystathionase activity (Fig. 3). In contrast, extracts of cells from patients with either $B_{6}$-responsive or $B_{6^{-}}$ unresponsive cystathioninuria exhibited no discernable cystathionase activity when assayed without added coenzyme. Addition of PLP up to $1.0 \mathrm{mM}$ to normal and abnormal cell extracts resulted in striking differences: in the presence of increasing
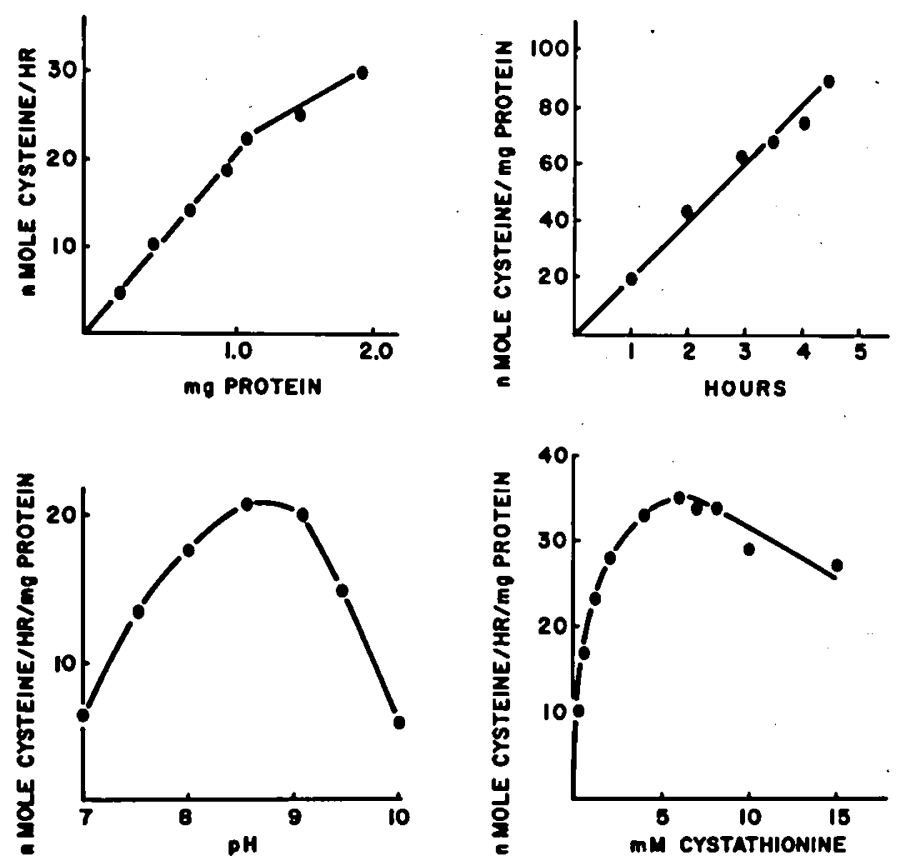

Fig. 1. Factors affecting the hydrolysis of cystathionine by crude extracts of normal long term lymphoid cell lines. See text for experimental details. 


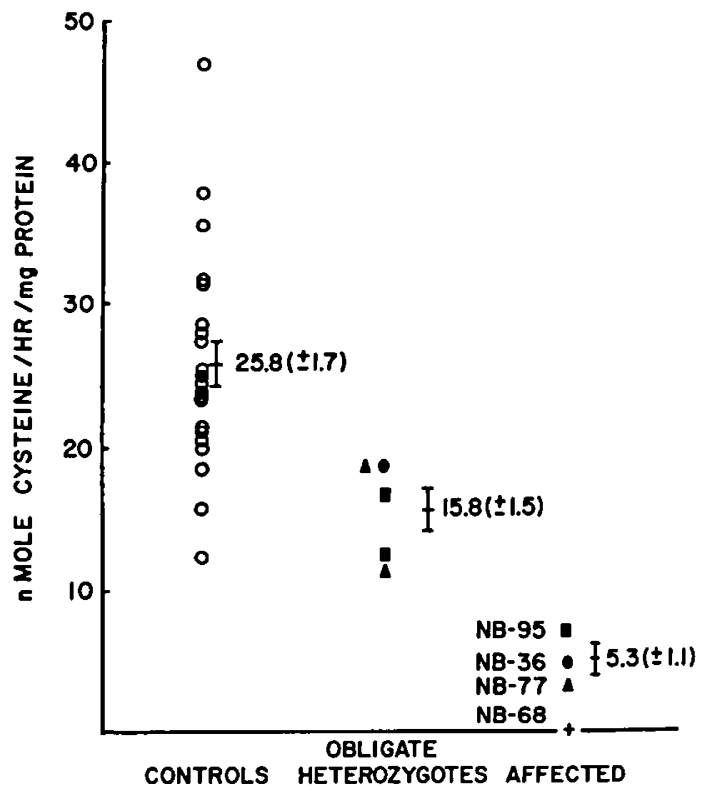

Fig. 2. Distribution of cystathionase activity in extracts of long term lymphoid cell lines established from 21 normal control subjects $(O)$; from three cell lines of patients with $\mathrm{B}_{6}$-responsive cystathioninuria, NB-36 (•), NB-95 (ם), NB-77 (A); from one cell line from a patient with $\mathrm{B}_{6}$-unresponsive cystathioninuria (+); and from five corresponding obligate heterozygotes for the $\mathrm{B}_{6}$-responsive form(s). The value for each group gives the mean $\pm \mathrm{SE}$. Each point represents the average of two to seven determinations.

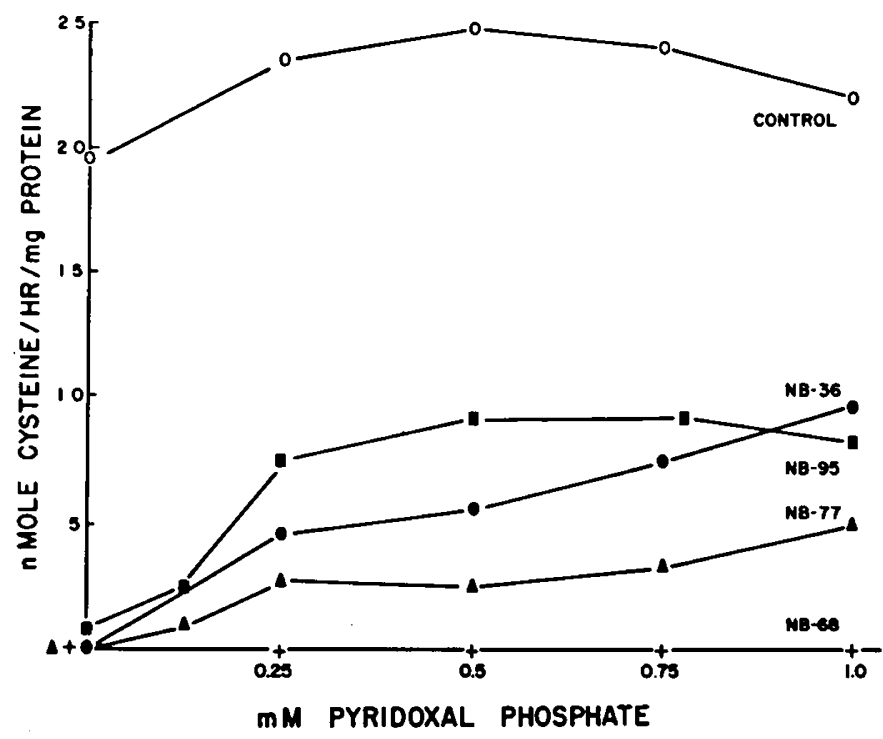

Fig. 3. Effects of increasing concentrations of PLP on cystathionase activity in extracts of lymphoid cell lines from a normal control subject; from three patients with $\mathrm{B}_{6}$-responsive cystathioninuria; and from one patient with $\mathrm{B}_{6}$-unresponsive cystathioninuria. Symbols are the same as in Figure 2.

concentrations of PLP, the extract of normal cells had little change in cystathionase activity up to $0.75 \mathrm{mM}$ and a slight decrease at $1.0 \mathrm{mM}$. Extract of cells from line NB-36, established from a $B_{6}$-responsive patient, showed a steady increase in cystathionase activity with increasing PLP concentration; at 1 $\mathrm{mM}$ PLP the specific activity increased to 9.4. Extract of cells from a second such patient (line NB-95) increased to 8.1, whereas that from a third (line NB-77) was least stimulated by $\mathrm{PLP}$, increasing to only $4.8 \mathrm{nmol}$ cysteine $/ \mathrm{mg}$ protein $/ \mathrm{hr}$. No stimulation was observed when up to $1.0 \mathrm{mM}$ PLP was added to an extract of cells from a $\mathbf{B}_{6}$-unresponsive patient (line NB68 ). The ratio of activity with $0.25 \mathrm{mM}$ PLP to activity without added PLP was significantly greater in extracts of cells from the obligate heterozygotes than in extracts of normal cells (Table 1).

On immunoelectrophoresis a single immunoprecipitin band could be seen between an ammonium sulfate preparation of normal human liver and rabbit antiserum developed to the purified fraction of human liver, showing that the antiserum was monospecific for cystathionase (Fig. $4 A$ ). Rabbit antiserum to rat liver cystathionase was also monospecific (Fig. $4 B$ ). With agar double diffusion analysis and the use of a specific stain for cystathionase activity, a band of identity was demonstrated between the cystathionase of human liver and those of human kidney and brain (Fig. $4 C$ ). With antiserum to rat liver cystathionase, the antigenic identity of the cystathionases of adult rat liver, fetal rat liver, and rat kidney was demonstrated (Fig. $4 D$ ). Antigenic identity of fetal and adult liver cystathionase also is present in the rhesus monkey (Fig. $4 E$ ). However, only partial identity among the cystathionases extracted from the livers of various vertebrate species was demonstrated using the antiserum to human liver cystathionase (Fig. $4 F$ ). These species differences are evident, too, in differences in the mobility of the enzymes on immunoelectrophoresis (Fig. 4G). The human and bovine enzyme proteins migrated most rapidly towards the anode, the bovine appearing slightly faster. The enzyme from monkey liver moved considerably slower than the human enzyme, as did the rabbit liver enzyme. Liver cystathionase from two rodents, mouse and rat, moved slightly toward the cathode.

Consistent with the specificity demonstrated above, cystathionase in extracts of normal human liver exhibited antigenic identity with that in extracts from normal human long term lymphoid cell lines when diffused against antiserum to the human liver enzyme. This precipitin shared by extracts from normal liver and normal long term lymphoid cell lines joined with a band of identity the precipitin of the enzyme protein from the cells of the $B_{6}$-responsive line NB-36. No precipitin band was formed with the extract of the line (NB-68) from the $\mathrm{B}_{6}$-unresponsive patient (Fig. $5 A$ ); this lack of cross-reactivity persisted even at a protein concentration for this extract of 110 $\mathrm{mg} / \mathrm{ml}$. Extract of the other lymphoid lines from $\mathrm{B}_{6}$-responsive patients (NB-95 and NB-77) also each had a precipitin band sharing antigenic identity with the enzyme protein from normal cells. This band, however, was too faint to be photographed. When the immune complexes from the extracts of normal human liver and of normal and the abnormal lymphoid cell lines NB-36, NB-95, and NB-77 were treated with the enzyme stain specific for cystathionase, activity was demonstrated in the extracts from liver and from normal cells, but no activity staining was observed in the immunoprecipitin band from the line NB-36 (Fig. 5B) or from lines NB-95 and NB-77. Activity

Table 1. The effect of PLP on cystathionase activity in long term lymphoid cell lines established from normal subjects and from obligate heterozygotes for $B_{6}$ responsive cystathioninuria ${ }^{1}$

nmol cysteine formed/ $\mathrm{mg}$ protein/hr

\begin{tabular}{lcccc}
\multicolumn{1}{c}{ Donor } & $\begin{array}{c}\text { No. of } \\
\text { subjects }\end{array}$ & 0 PLP & $\begin{array}{c}0.25 \mathrm{mM} \\
\text { PLP }\end{array}$ & \multicolumn{1}{c}{$\mathbf{R}^{2}$} \\
\hline Normal & 5 & 18.49 & 21.79 & 1.18 \\
& & $( \pm 1.44)$ & $( \pm 1.59)$ & $( \pm 0.05)$ \\
B - Responsive heter- & 5 & 11.68 & 16.98 & $1.48^{3}$ \\
ozygote & & $( \pm 1.44)$ & $( \pm 1.56)$ & $( \pm 0.07)$ \\
\hline
\end{tabular}

${ }^{1}$ The values for each group are the mean $\pm \mathrm{SE}$.

${ }^{2} \mathrm{R}=$ activity at $0.25 \mathrm{mM}$ PLP/activity without added PLP.

${ }^{3}$ Significantly different from controls determined by Student's $t$-test $(P<0.01)$. 
A

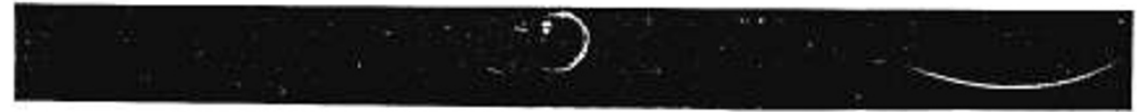

B

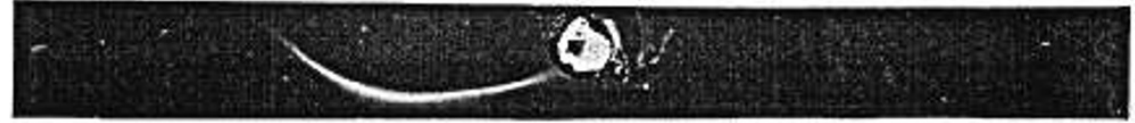

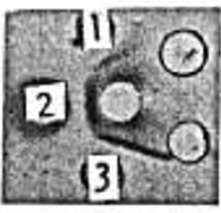

C

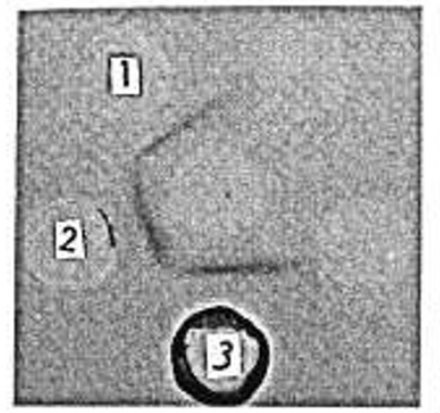

D

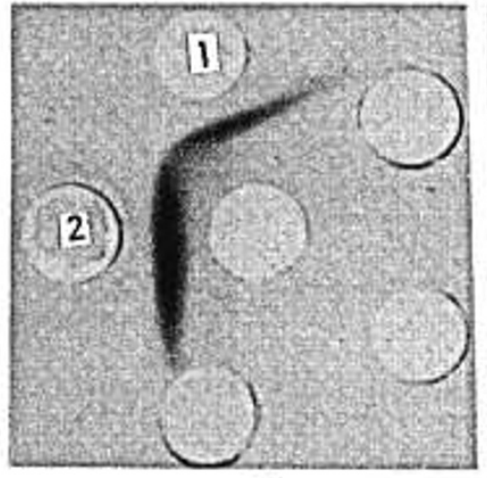

E

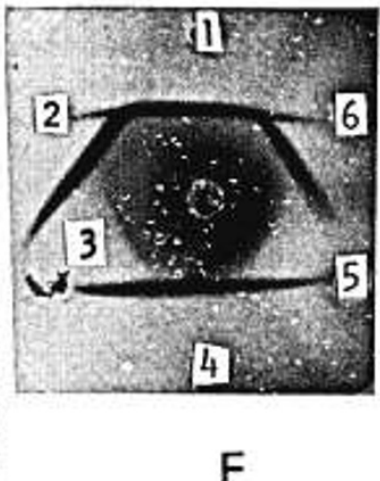

F
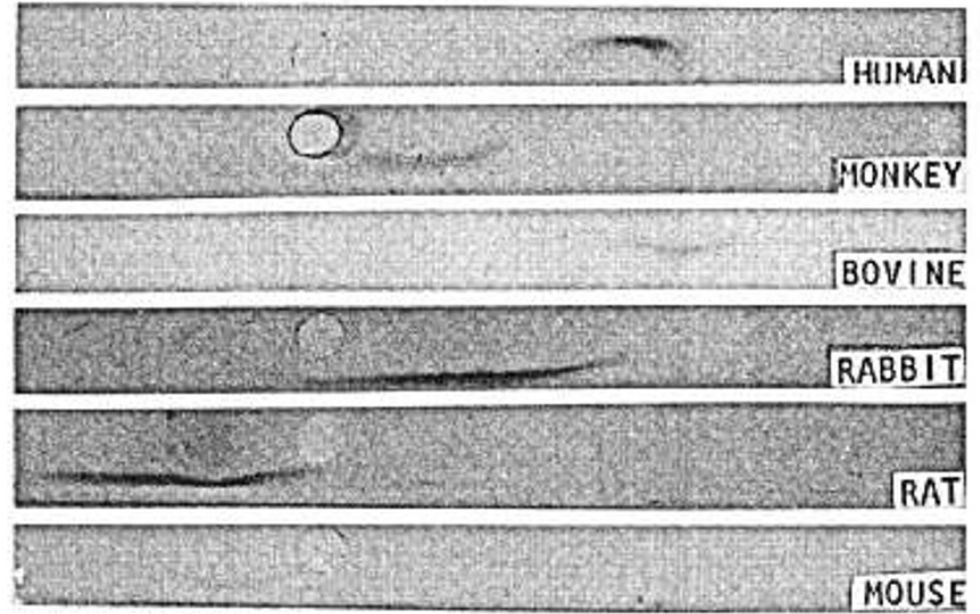

G

Fig. 4. A: immunoelectrophoresis on $0.7 \%$ agarose. Antigen well contains $45-65 \%$ amonium sulfate saturation fraction of human liver extract. Trench contains rabbit antiserum to human liver cystathionase. B: immunoelectrophoresis on $1 \%$ agarose. Antigen well contains 55-70\% ammonium sulfate saturation fraction of rat liver extract. Trench contains $\gamma$ globulin fraction of rabbit antiserum to rat liver cystathionase. $C$ : agar double diffusion. Well 1 contains concentrated extracts of human brain, well 2 contains the ammonium sulfate fraction of human liver, and well 3 contains a concentrated extract of human kidney. The center well contains rabbit antiserum to human liver cystathionase, diluted 4-fold with saline. Immunoprecipitates were stained for cystathionase activity (24). D: agar double diffusion. Well 1 contains the ammonium sulfate fraction of adult rat liver; wells 2 and 3 contain concentrated extracts of rat kidney and fetal rat liver, respectively. The center well contains rabbit antiserum to rat liver cystathionase, diluted 4-fold. Staining as in $C$. E: agar double diffusion. Wells 1 and 2 contain concentrated extracts of fetal and adult monkey liver, respectively. The center well contains a 2-fold dilution of rabbit antiserum to human liver cystathionase. Staining as in $C$. $F$ : agar double diffusion. Wells 1 and 4 contain the ammonium sulfate fraction of human liver. Wells $2,3,5$, and 6 contain fractions of monkey, rabbit, mouse, and bovine liver, respectively. The center well contains rabbit antiserum to human liver cystathionase. Staining as in $C$. $G$ : immunoelectrophoresesis on $1 \%$ agarose. The antigen wells contain ammonium sulfate fractions of liver from the vertebrate species indicated. Each trench contains rabbit antiserum to human liver cystathionase, diluted 2-fold. Staining as in $C$.

staining was also not observed with the extracts of the line NB68 from the $B_{6}$-unresponsive patient. When, however, $1.0 \mathrm{mM}$ PLP was added to the extracts of the lymphoid lines NB-36, NB-95, and NB-77 before immunodiffusion, cystathionase activity was then demonstrated in the antigen-antibody complex. Addition of PLP to lymphoid line NB-68 before immunodiffusion did not elicit cystathionase activity (Fig. $5 C$ and $D$ ).

The $\gamma$-globulin fraction of antiserum to normal human hepatic cystathionase inhibited cystathionase activity when added to extract of normal cells or of cells from the three patients with $B_{6}$-responsive cystathioninuria. Inhibition in each case was approximately linear with increasing antibody concentrations, up to $40-55 \%$ inhibition with $0.5 \mu$ l globulin preparation (Fig. 6). Preimmune $\gamma$ globulin did not appreciably affect enzyme activity.

Blocking of antibody sites for cystathionase by extracts of the affected cells occurred with the extract from line NB-36 and marginally with the extract of line NB-95 (Fig. 7). After preincubation of the antibody with the extract from line NB-36 there was a decrease in the inhibition of the normal cell extract by the antibody from 54.2 to $39.8 \%$. When the experiment was repeated with twice the concentration of extract of the same line, inhibition of the activity of normal cell extract decreased further to $29.5 \%$. With the extract of cells from line NB-95, 


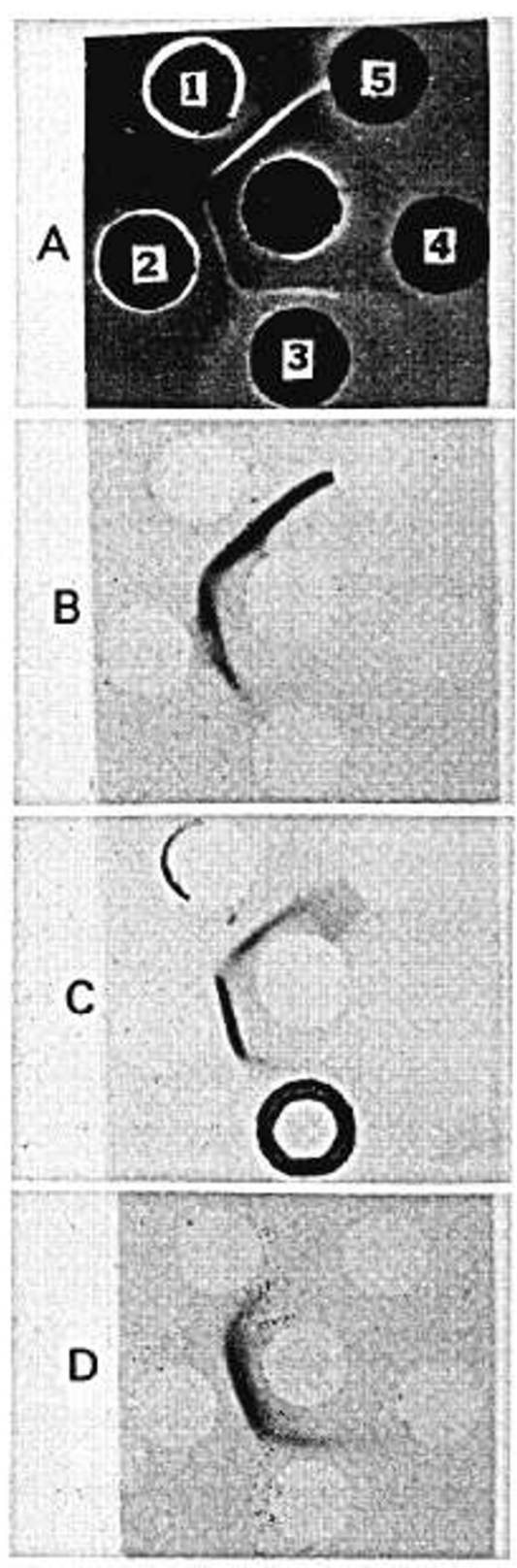

Fig. 5. Agarose double immunodiffusion of extracts of $B_{6}$-responsive and $\mathrm{B}_{6}$-unresponsive long term lymphoid cell lines. Rabbit antiserum to human liver cystathionase was placed in the center well. $A$ : outer wells contain extracts from human liver (well 1) and the following lymphoid cell line extracts: normal (well 2), $\mathrm{B}_{6}$-responsive line NB 36 (well 3) and $B_{6}$-unresponsive line NB-68 (well 4 ). Well 5 contains saline. All extracts from lymphoid cell lines have total protein contents of 65-70 $\mathrm{mg} / \mathrm{ml}$. The unstained immune precipitates are shown. $B$ : same as $A$, stained for cystathionase activity. $C$ : result obtained when $1.0 \mathrm{mM}$ PLP was added to all extracts before immunodiffusion and the plate stained as in $B$. Copyright 1975 by the American Association for the Advancement of Science. $D$ : the outer wells contain lymphoid cell line extracts from line NB-77 (well 1), a normal control (well 2), and $B_{6}$-responsive line NB-95 (well 3). These extracts contain a total protein of $100 \mathrm{mg} /$ $\mathrm{ml}$. PLP (1.0 mM) was added to the extracts before immunodiffusion and the plate stained as in $B$.

the decrease in inhibition of normal cell activity was slight, from 42 to $38 \%$ and decreasing only slightly to $32.9 \%$ when the concentration of protein from the abnormal cells was increased 2-fold. On the other hand, preincubation with extracts of cells from the $B_{6}$-unresponsive line NB-68 and from the $B_{6}$-responsive line NB-77 did not alter the degree of inhibition of the normal enzyme by antibody, nor did doubling the concentration of these extracts in the preincubation cause any significant change in percentage of inhibition.

\section{DISCUSSION}

For our investigation of cystathionase deficiency, optimum conditions were established for assay of the enzyme in cultured lymphoid cells, since the activity in skin fibroblasts is so low. The specific activity of cystathionase in extracts of lymphoid

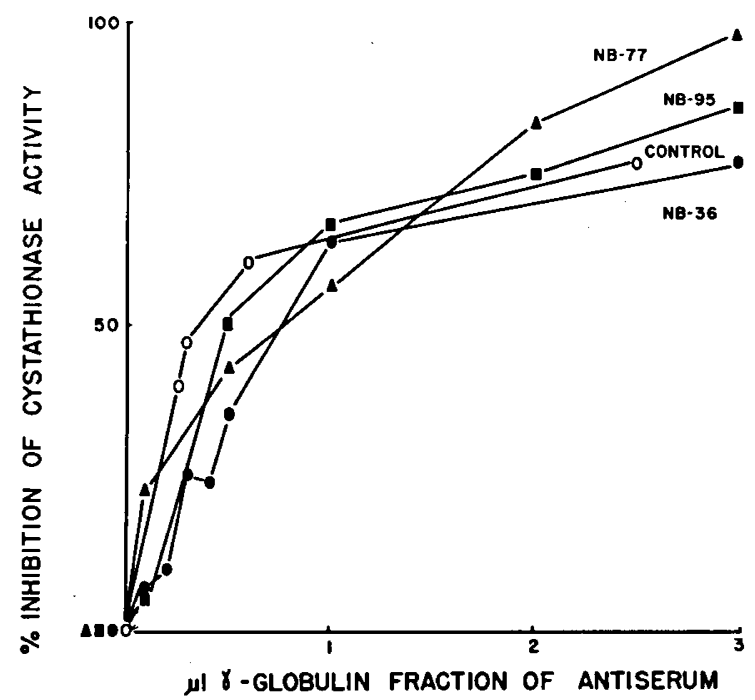

Fig. 6. Immunoinhibition of cystathionase in long term lymphoid cell lines with the $\gamma$ globulin fraction of rabbit antihuman-cystathionase serum. The extracts used are from a normal control and from $\mathbf{B}_{6^{-}}$ responsive cell lines. The symbols are the same as in Figure 2. The concentration of PLP in the assay was $1.0 \mathrm{mM}$.

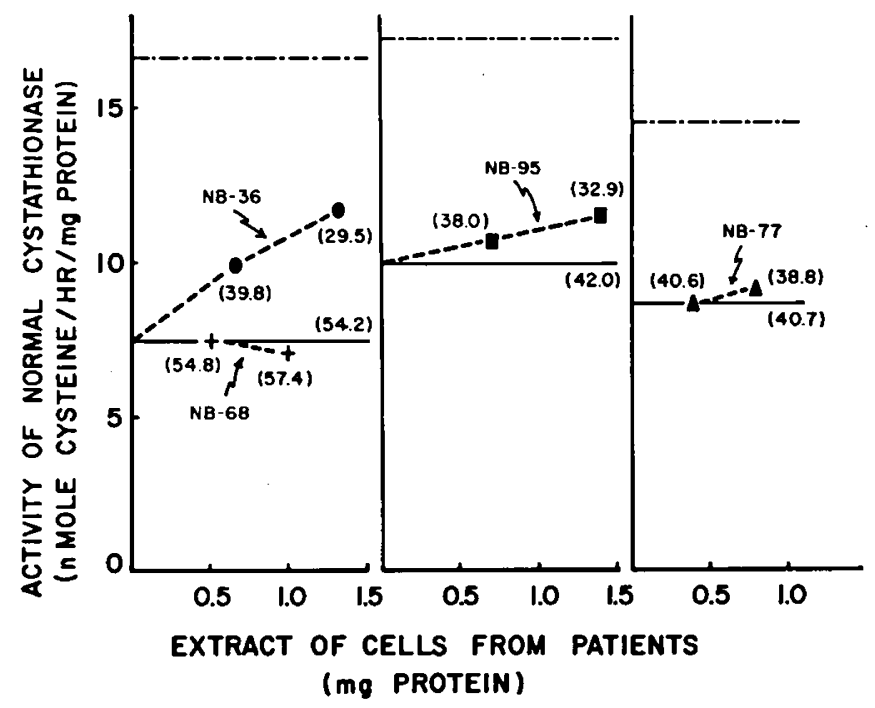

Fig. 7. Blocking of antibody-binding sites for cystathionase by extracts of lymphoid cells from patients with cystathioninuria. In each experiment the upper horizontal line (-•-•-) gives the activity of an aliquot of normal lymphoid cell extract, the lower line (-) the activity after addition of a fixed amount of rabbit antibody to normal human liver cystathionase; the figure in parentheses at the right of each lower line gives the percentage of inhibition achieved. Portions of extracts of lymphoid cells from the patients were incubated with the antibody before addition of the normal extract; the figure in parentheses at each point gives the percentage of inhibition found. All assays were carried out in the absence of added PLP, in order to measure only the normal enzyme. The symbols are the same as in Figure 2. 
lines from normal subjects was found to average approximately 4- to 5-fold greater than that in extracts from most normal skin fibroblast cultures. Indeed, some normal skin fibroblasts failed to show any cystathionase activity. This finding was true despite the fact that we used our radioactive, more sensitive (28), assay for cystathionase. For this reason, skin fibroblasts do not appear to be suitable for the study of primary cystathioninuria, although Bittles and Carson (4) have reported on a patient with cystathioninuria whose cultured fibroblasts had $15 \%$ of mean control fibroblast cystathionase activity (using our less sensitive (12) assay).

The utilization of antiserum to purified human liver cystathionase allowed us to gain more insight into the heterogeneity of cystathionase deficiency. The antiserum reacted with the enzyme present in the cultured human lymphoid cells and with the enzyme present in all vertebrate species studied. The extent of reaction of the antiserum with an extract of vertebrate liver appears to be dependent on the phylogenetic distance between the species. On agar double diffusion analysis, the rhesus monkey and bovine enzymes are more like the human enzyme than are the rabbit, rat, or mouse enzymes. Even the monkey enzyme, however, has only partial identity with the human enzyme, as seen by spur formation at the junction of their respective precipitin bands (Fig. $4 F$ ). By comparison, erythrocyte 6-phosphogluconate dehydrogenase appears to have undergone less evolutionary change than cystathionase, since it was not possible to detect immunologic differences between the human and rhesus monkey enzymes (14). The components within the enzyme molecule which are common to the various species probably are a legacy of a common ancestor and may be those components essential to enzyme specificity and located nearer the catalytic site of the enzyme protein. The differences among the various species in mobility on immunoelectrophoresis suggest that changes in amino acid composition during evolution involved charged amino acids as well as others. Noteworthy is the finding that rabbit antiserum against human cystathionase cross-reacts with the rabbit enzyme (Fig. $4, F, G$ ). In most instances the animal used for production of antiserum does not produce antibodies to those antigenic determinants which are present on its own enzyme protein. Some exceptions have been reported (34). The antigenic identity observed among the enzymes from various organs of a given species, coupled with the partial identity observed among the species, is evidence that cystathionase is a species-specific rather than an organ-specific enzyme. Other examples of gradual divergence of enzymes during evolution have been reported $(13,15)$. Both rat and monkey fetal liver enzymes appear to be antigenically identical with the respective adult forms. This identity is not found with the human liver enzyme, which is either virtually absent or present in the fetus in a form not detectable by the antiserum $(24,39)$.

Genetic heterogeneity in primary cystathioninuria is clinically evident from the observation that, although most patients respond biochemically to massive doses of vitamin $B_{6}$, some patients do not. We have studied long term lymphoid cell lines from three $B_{6}$-responsive patients and one $B_{6}$-unresponsive patient and have obtained evidence for the occurrence of two and possibly three different mutations leading to different alterations in the cystathionase molecule. A distinction can be made among normal cells, cells from the responsive patients studied, and cells from the unresponsive patient studied on the basis of the effect of PLP, the coenzyme form of vitamin $B_{6}$, on the cystathionase activity of cell extracts. Extracts of normal cells, when assayed in the absence of PLP, had a specific activity approximately $89 \%$ of that achieved in the presence of $1 \mathrm{mM}$ PLP. In contrast, no discernable activity was observed in any of the affected cell lines without added PLP. With the addition of increasing amounts of PLP to extracts of cells NB-36, NB-95, and NB-77, established from $B_{6}$-responsive patients, cystathionase became measurable, reaching at $1 \mathrm{mM}$ PLP an average of 37,26 , and $16 \%$, respectively, of the mean normal value obtained at $0.25 \mathrm{mM}$. Extracts of the lymphoid line NB68 from the unresponsive patient, on the other hand, could not be activated by the coenzyme even at the highest concentration of PLP employed. This in vitro evidence parallels the in vivo findings of inherited vitamin dependence. The response of the enzyme extracts from the obligate heterozygotes to $0.25 \mathrm{mM}$ PLP, as compared to the response without added PLP, was significantly greater than that of the normal and intermediate between the responses of the normal and affected cells, probably reflecting the presence of the abnormal enzyme protein along with the wild type enzyme.

These results suggest also that the defective enzyme(s) in each of the three $B_{6}$-responsive lines has an altered interaction with the coenzyme; addition of large concentrations of PLP to the assay mixture allows the otherwise inactive apoenzyme to combine with sufficient coenzyme for some activity to be expressed. The defect in the $\mathrm{B}_{6}$-unresponsive cells, however, may reflect either absence of the enzyme protein or alteration in such a way that partial restoration of cystathionase activity by excess PLP cannot be achieved. The possibility that the four cases of primary cystathioninuria we have studied may result from an inability to utilize PLP is ruled out by the normal activity of $S$-adenosylmethionine decarboxylase, another $\mathrm{B}_{6}$-dependent enzyme (40), in extracts of the affected cells. The possibility that PLP activates an alternate route of cysteine formation also must be considered. The immunodiffusion results, however, show directly that cystathionase activity is elicited in the enzyme-antibody precipitate from extracts of cell lines from $\mathrm{B}_{6}$-responsive patients (NB-36, NB-95, NB-77) when PLP is added (Fig. 5, $C$ and $D$ ). The inhibition experiments, which show that the antiserum inhibits the PLP-activated cystathionase of the $B_{6}$-responsive cell lines, give quantitative data on the specific cross-reactivity of the cystathionase protein in all three of the $\mathbf{B}_{6}$-responsive lymphoid cell lines with the antibody developed to the normal liver enzyme. Taken together, these experiments demonstrate that the effect of PLP is on the abnormal protein and not on a possible alternative pathway of cysteine formation. Finally, chemical catalysis of the cleavage of cystathionine by PLP is ruled out because in the inhibition experiment product formation is proportional to residual enzyme protein and not to the concentration of cofactor, which was the same in all assay tubes.

The presence of cross-reacting inactive apoenzyme in the lymphoid lines from the $\mathrm{B}_{6}$-responsive patients and its absence from the cells of the $B_{6}$-unresponsive patient is demonstrated by the agar double diffusion analysis. In the $\mathrm{B}_{6}$-unresponsive line, extracts of which also were unable to block the antibody combining site, the findings suggest that either the cells produce an enzyme protein which has lost both its catalytic activity and its antigenic determinants or that synthesis has been abolished entirely. It is also possible that these cells may be making amounts of cystathionase too little to be detected by the methods employed or that there is production of an altered apoenzyme so labile that the steady state concentration is too low to measure. Various genetic mechanisms might be responsible for the defect, such as an ineffective messenger RNA or a modification of the structural gene producing a deletion of the enzyme protein or premature termination of the polypeptide chain (no-sense mutation) (37).

The results with the $\mathrm{B}_{6}$-responsive lines indicate that the $\mathrm{B}_{6}$ responsive form(s) of cystathioninuria stem from a structural mutation at the cystathionase locus (missense mutation), which appears to have produced changes located at the coenzyme binding site. There is also the possibility of production of altered apoenzyme(s) subject to abnormally rapid degradation, the rate of degradation being mitigated by the coenzyme. Extracts of cells from one $B_{6}$-responsive patient (line NB-36) were able to block the antibody combining site, demonstrating quite convincingly that this line synthesizes an enzyme protein immunologically indistinguishable from the normal enzyme. Extract of cells from line NB-95 competed only marginally with 
the normal enzyme for the antibody combining site and extract of cells from line NB-77 did not compete at all, suggesting possibly a different mutation resulting in cystathionase deficiency. The antibody-blocking technique can reveal less extensive structure alteration than the complete loss of a determinent shown by immunodiffusion techniques. The blocking procedure in most instances can identify and distinguish immunologically between active and inactive enzyme, but also is able to measure the primary interaction and binding between enzyme protein and antibody. Thus, Neuwelt et al. (22) have demonstrated that the primary enzyme-antibody binding test distinguished between normal and abnormal enzymes which could not be distinguished by routine immunoprecipitation techniques. In the present experiments, it is possible that increased concentrations of altered enzymes from lines NB-95 and NB-77 could have competed effectively with the normal enzyme for the antibody binding site. It is evident, however, that the concentration required would have had to have been considerably greater than that used with extract of cells from line NB-36, thereby producing different slopes in the experiments of Fig. 7. Alternatively, the lack of or reduced competition for the antibody combining site observed in the lysates from these two cell lines may have been caused by reduction in the total amount of enzyme present in these cells. Whether or not the defect(s) present in the $\mathrm{B}_{6}$ responsive lines, NB-95 and NB-77, are the same cannot be discerned from the present studies.

Several other inborn errors of metabolism have been shown immunologically to be heterogeneous $(5,7,29)$. In addition to being of theoretic genetic interest, studies of the immunologic properties of enzymes involved in inborn errors of metabolism are also of practical value if enzyme replacement is considered. In totally deficient individuals who lack any cross-reacting protein, normal enzyme used for replacement therapy could be treated as a foreign antigen, resulting in an immune response.

\section{CONCLUSION}

The heterogeneity of primary cystathioninuria has been studied by immunochemical and enzymatic methods, using long term lymphoid cell lines as the source of enzyme. Extracts of normal cell lines had cystathionase activity in the absence or presence of added PLP in the assay system. Extracts of lines established from three vitamin $\mathrm{B}_{6}$-responsive patients had no cystathionase activity without added PLP, but could be activated by addition of the cofactor. On agar double diffusion against rabbit antibody to normal human hepatic cystathionase, each of these extracts displayed a band of identity with the normal enzyme; however, in one case only was the extract able to compete with normal enzyme for the antibody combining sites. Extracts of a lymphoid cell line derived from a $\mathrm{B}_{6}$-unresponsive patient had no cystathionase activity in the absence or presence of PLP, did not form a precipitin with the antibody, and did not compete for the antibody combining sites. Thus, cells from the $\mathrm{B}_{6}$-unresponsive patient either do not synthesize cystathionase at all or produce a molecule so altered as to lack both activity and the ability to combine with the antibody. The lymphoid lines established from the $B_{6}$-responsive patients produce cystathionase molecules having an altered interaction with the cofactor, PLP; in two of the three cases, the ability to block antibody combining sites also may have been affected. It is also possible that the low activity observed in the extract of cells from the $\mathrm{B}_{6}{ }^{-}$ responsive forms, and the lack of activity in the extract of cells from the $B_{6}$-unresponsive form may be the result of increased degradation of the mutant enzyme(s).

\section{REFERENCES AND NOTES}

1. Alhadeff, J. A., Miller, A. L., Wenass, H., Vedvick, T., and O'Brien, J. S.: Human liver $\alpha$-L-fucosidase. Purification, characterization and immunological studies. J. Biol. Chem., 250: 7106 (1975).

2. Arnon, R., and Shapira, E.: Antibodies to papain: A selective fractionation according to inhibitory capacity. Biochemistry, 6: 3942 (1967).
3. Beratis, N. G., and Hirschhorn, K.: Establishment of long-term lymphoid cell lines. Mamm. Chromosomes Newsletter, 14: 114 (1973).

4. Bittles, A. H., and Carson, N. A. J.: Cystathionase deficiency in fibroblast cultures from a patient with primary cystathioninuria. J. Med. Genet., 11: 121 (1974).

5. Brown, P. E., Hougie, C., and Roberts, H. R.: The genetic heterogeneity of hemophilia B. N. Engl. J. Med., 283: 61 (1970).

6. Churchich, J. E., and Bieler, J.: Reactivity of pyridoxal-5-phosphate residues of cystathionase. Biochim. Biophys. Acta, 229: 813 (1971).

7. Dreyfus, J. C., and Alexandre, Y.: Immunological studies on glycogen storage diseases type III and V. Demonstration of the presence of an immunoreactive protein in one case of muscle phosphorylase deficiency. Biochem. Biophys. Res. Commun., 44: 1364 (1971).

8. Finkelstein, J. D., Kyle, W. E., and Harris, B. J.: Methionine metabolism in mammals: Regulation of homocysteine methyltransferases in rat tissues. Arch. Biochem. Biophys., 146: 84 (1971).

9. Finkelstein, J. D., Mudd, S. H., Irreverre, F., and Laster, L.: Deficiencies of cystathionase and homoserine dehydratase activities in cystathioninuria. Proc. Nat. Acad. Sci., 55: 865 (1966).

10. Fleisher, L. D., Tallan, H. H., Beratis, N. G., Hirschhorn, K., and Gaull G. E.: Cystathionine synthase deficiency: Heterozygote detection using cultured skin fibroblasts. Biochem. Biophys. Res. Commun., 55: 38 (1973).

11. Frimpter, G. W.: Cystathioninuria: Nature of the defect. Science, 149: 1095 (1965).

12. Gaull, G. E., Rassin, D. K., and Sturman, J. A.: Enzymatic and metabolic studies of homocystinuria: Effects of pyridoxine. Neuropädiatrie, 1: 199 (1969).

13. Golan, R., Yaov, B., and Arnon, R.: Immunological relationships among hexoseaminidases of different species. Immunochemistry, 13: 485, (1976).

14. Golan, R., and Szeinberg, A.: Immunochemical study of relationships between erythrocyte 6-phosphogluconate dehydrogenase of various mammalian species. Comp. Biochem. Physiol., 48B: 161 (1974).

15. Hanke, N., Prager, E. M., and Wilson, A. C.: Quantitative immunological and electrophoretic comparison of primate lysozymes. J. Biol. Chem., 248 2824 (1973).

16. Harris, H., Penrose, L. S., and Thomas, D. H. H.: Cystathioninuria. Ann. Hum. Genet., 23: 442 (1959).

17. Levy, H. L., Mudd, S. H., and Madigan, P. M.: Pyridoxine-unresponsive cystathioninemia. Pediat. Res., 7: 390 (1973).

18. Li, J. B., and Knox, E. W.: Titration of tryptophan oxygenase antigen by immunoinhibition. J. Biol. Chem., 247: 7546 (1972).

19. Lowry, O. H., Rosebrough, N. J., Farr, A. L., and Randall, R. H.: Protein measurement with the Folin phenol reagent. J. Biol. Chem., 193: 265 (1951).

20. Lyon, I. C. T., Procopis, P. G., and Turner, B.: Cystathioninuria in a well baby population. Acta Paediat. Scand., 60: 324 (1971).

21. Matsuo, Y., and Greenberg, D. M.: A crystalline enzyme that cleaves homoserine and cystathionine. Il. Prosthetic group. J. Biol. Chem., 230: 561 (1958).

22. Neuwelt, E., Kohler, P. F., and Austin, J.: Primary enzyme immunoassay (PEIA): Studies of the mutant enzyme in metachromatic leukodystrophy (primary enzyme immunoassay of arylsulfatase-A). Immunochemistry, 10: 767 (1973).

23. Nordman, Y., Shapira, F., and Dreyfus, J. C.: A structurally modified liver aldolase in fructose intolerance: Immunological and kinetic evidence. Biochem. Biophys. Res. Commun., 31: 884 (1968).

24. Pascal, T. A., Gillam, B. M., and Gaull, G. E.: Cystathionase: Immunochemical evidence for absence from human fetal liver. Pediat. Res., 6: 773 (1972).

25. Pascal, T. A., Tallan, H. H., and Gillam, B. M.: Hepatic cystathionase: Immunochemical and electrophoretic studies of the human and rat forms. Biochim. Biophys. Acta, 285: 48 (1972).

26. Perry, T. L., Robinson, G. C., Teasdale, J. M., and Hansen, S.: Concurrence of cystathioninuria, nephrogenic diabetes insipidus and severe anemia. $\mathrm{N}$. Engl. J. Med., 276: 721 (1967).

27. Rassin, D. K.: Transmethylation and transsulfuration enzymes in rat brains: Their subcellular distribution. In: S. Berl, D. D. Clarke, and D. Schneider: Metabolic Compartmentation and Neurotransmission, p. 559 (Plenum, New York, 1975).

28. Rassin, D. K., and Gaull, G. E.: Subcellular distribution of enzymes of transmethylation and transsulphuration in rat brain. J. Neurochem., 24: 969 (1975).

29. Rubinstein, H. M., Dietz, A. A., Hodges, L. K., Lubrano, T., and Czebotar, V.: Silent cholinesterase gene: Variations in the properties of serum enzyme in apparent homozygotes. J. Clin. Invest., 49: 479 (1970).

30. Salmon, S. E., Cline, M. J., Schultz, J., and Lehrer, R. I.: Immunologic study of genetic leukocyte defect. N. Engl. J. Med., 282: 250 (1970).

31. Scheidegger, J. J.: Une micro-méthode de l'immunoelectrophorèse. Int. Arch. Allergy, 7: 103 (1955).

32. Schneider, J. A., Bradley, K. H., and Seegmiller, J. E.: Transport and intracellular fate of cysteine- ${ }^{35} S$ in leukocytes form normal subjects and patients with crystinosis. Pediat. Res., 2: 441 (1968).

33. Scott, R. C., Dassell, S. W., Clark, S. H., Chiang-Teng, C., and Swedberg, K. R.: Cystathioninemia: A benign genetic condition. J. Pediat., 76: 571 (1970).

34. Selig, D., and Chilson, O. P.: Immunoenzymology of AMP-diaminase. J. Immunol., 103: 725 (1969). 
35. Shaw, K. N. F., Lieberman, E., Koch, R., and Donnell, G. N.: Cystathioninuria. Amer. J. Dis. Child., 113: 119 (1967).

36. Snell, E. E., Fasella, P. M., Braunstein, A., and Rossi Fanelli, A.: Chemical and Biological Aspects of Pyridoxal Catalysis, pp. 1-11 (Macmillan Co., New York, 1963)

37. Stanbury, J. B., Wyngaarden, J. B., and Fredrickson, D. S.: The Metabolic Basis of Disease, Ed. 3, p. 10 (McGraw-Hill, New York, 1972)

38. Steinmann, B., and Niederwieser, A.: Manuscript in preparation.

39. Sturman, J. A., Gaull, G. E., and Räihä, N. C. R.: Absence of cystathionase in human fetal liver: Is cystine essential? Science, 169: 74 (1970).

40. Sturman, J. A., and Kremzner, L. T.: Polyamine biosynthesis and vitamin $B_{6}$ deficiency. Evidence for pyridoxal phosphate as coenzyme for $S$-adenosylmethionine decarboxylase. Biochim. Biophys. Acta, 372: 162 (1974).

41. Tada, K., Yoshida, T., Yokoyama, Y., Sato, T., Nakagawa, H., and Arakawa, T.: Cystathioninuria not associated with vitamin $\mathrm{B}_{6}$ dependency: A probably new type of cystathioninuria. Tohoku J. Exp. Med., 95: 235 (1968).

42. Tallan, H. H., Pascal., T. A., Schneidman, K., Gillam, B. M., and Gaull, G. E.: Homolanthionine synthesis by human liver cystathionase. Biochem. Biophys. Res. Commun., 43; 303 (1971).
43. Tedesco, T. A., and Mellman, W. J.: Galactosemia: Evidence for a structural gene mutation. Science, 172: 727 (1971).

44. Uriel, J.: Characterization of enzymes in specific immune-precipitates. Ann. N. Y. Acad. Sci., 103: 956 (1963).

45. We thank Drs. C. Parker, Y. Wada, B. Steinmann and R. Gitzelmann for providing blood for culture of lymphoid cell lines from patients with primary cystathioninuria. We also thank Dr. J. Sturman for performing the $S$-adenosylmethionine decarboxylase assays and Dr. M. Kehoe and Mr. D. Pascal for helpful discussion and advice.

46. These studies were performed with the informed consent of the subjects or, in the case of children, with the informed consent of their parents.

47. This work was published in part (Science, 190: 1209 (1975)).

48. This research was supported by the New York State Department of Mental Hygiene, the Lalor Foundation, National Institutes of Health Genetics Center Grant GM-19443.

49. Requests for reprints should be addressed to: Theresa A. Pascal, Institute for Basic Research in Mental Retardation, 1050 Forest Hill Road, Staten Island, NY 10314 (USA).

50. Received for publication March 7, 1977

51. Accepted for publication May 25, 1977.
Autoxidation

Bohr effect

2,3-diphosphoglycerate

heme-heme interaction hemoglobin, fetal and adult methemoglobin

$\mathrm{P}_{50}$

\title{
Oxygen Affinity of Hemoglobins F and A Partially Oxidized to Methemoglobin: Influence of 2,3-Diphosphoglycerate
}

\author{
H. T. VERSMOLD, ${ }^{(39)}$ K. FÜRST, K. BETKE, AND K. P. RIEGEL \\ Division of Neonatology, Kinderklinik der Universität, Munich, Federal Republic of Germany
}

Summary

Oxygen equilibrium curves of partially autoxidized adult (HbA) and fetal hemoglobins (HbF) were determined at 275\% methemoglobin (met-Hb). Hemoglobin concentration of 5 $\mathrm{mM}$, pH 7.15 (Tris $0.05 \mathrm{M}$ ), and temperature of $37^{\circ}$ corresponded to intraerythrocytic in vivo conditions. With increasing met-Hb fractions the curves became shifted to the left and approached a hyperbolic form: $P_{50}$ of both $\mathrm{HbA}$ and $\mathrm{HbF}$ decreased in absence of 2,3-diphosphoglycerate (2,3-DPG) from about 13 to 7 Torr, and Hill's $n$ from 2.7 to 1.25 . Independent of the met-Hb fraction the alkaline Bohr effect was increased by 2,3-DPG. The allosteric effect of 2,3-DPG on $P_{50}$ decreased with increasing met-Hb. At all oxidation levels this effect was smaller on $\mathrm{HbF}$ than on $\mathrm{HbA}$ : At $50 \%$ met-Hb $P_{50}$ of $\mathrm{HbF}$ is increased by 0.7 Torr $/ \mathrm{mM}$ 2,3-DPG increase, $P_{50}$ of $\mathrm{HbA}$ by 1.3 Torr, respectively. There was no evidence of preferential autoxidation of $\alpha$ or non- $\alpha$ chains of the hemoglobin molecule.

Oxidized hemoglobin does not take part in oxygen transport. In addition a left-shifted, more hyperbolic curve means restricted oxygen unloading from the remaining active hemoglobin. Thus, from application of our results to clinical conditions it must be concluded that sustained methemoglobinemia, despite partial compensation by 2,3-DPG, may interfere with oxygen supply to tissue, particularly in the perinatal period, when $\mathbf{H b F}$ prevails.

\section{Speculation}

Tissue oxygen supply, as calculated from the present data on $\mathrm{O}_{2}$ capacity, $\mathbf{P}_{50}, 2,3-\mathrm{DPG}$ reactivity, Hill's $n$, and Bohr factors, appears to be markedly lowered in methemoglobinemia, particularly in presence of fetal hemoglobin. Reduced tissue oxygen supply in the perinatal period, in addition to a generalized cytochrome $b_{5}$ reductase deficiency $(22)$, might contribute to irreversable cerebral dysfunction in hereditary metheinoglobinemia.

It is well known that the oxygen affinity of partially oxidized $\mathrm{HbA}$ is increased $(8,10)$. However, this pronounced left shift of the hemoglobin oxygen equilibrium curve with increasing fractions of met-Hb in vitro was not observed in patients with sustained methemoglobinemia (for references see the reviews of Jaffé and Hsieh (14) and Kiese (17)). This discrepancy could have a methodologic cause. The in vitro experiments were performed on highly diluted solutions in presence of $0.6 \mathrm{M}$ inorganic phosphate. Both dilution (12) and inorganic phosphate (5) affect hemoglobin oxygen affinity. Moreover, the role of organic phosphates, mainly 2,3-DPG, as important allosteric effectors of hemoglobin, was not taken in account at that time.

More recently partially oxidized hemoglobins have attracted new attention. For instance, the question arose of whether the altered hemoglobin oxygen affinity could be responsible for the 